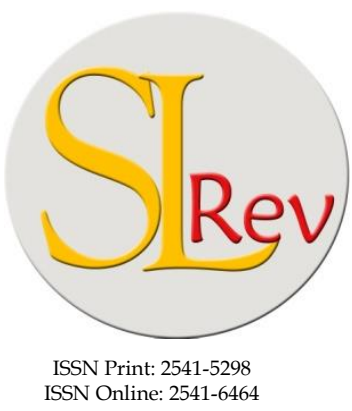

\section{Exercising No Harm Rule: Claims for Damage and Loss Due Climate Change Effects}

\author{
Mada Apriandi, ${ }^{\mathrm{a}^{*}}$ Febrian, ${ }^{\mathrm{a}}$ Murzal, ${ }^{\mathrm{a}}$ and $\operatorname{Ridwan}^{\mathrm{a}}$
}

Jalan Srijaya Negara, Palembang, South Sumatra 30139, Indonesia.

Phone: +62711-580063Fax: +62711-581179

E-mail: sriwijayalawreview@unsri.ac.id| sriwijayalawreview@gmail.com

Website: http://journal.fh.unsri.ac.id/index.php/sriwijayalawreview

$a^{*} \quad$ Faculty of Law, Universitas Sriwijaya. Indonesia. Corresponding author Mada Apriandi, email: madaapriandizuhir@fh.unsri.ac.id

\begin{tabular}{|c|c|}
\hline Article & Abstract \\
\hline $\begin{array}{l}\text { Keywords: } \\
\text { Climate change; Devel- } \\
\text { opment model; No-harm } \\
\text { rule; State's responsibil- } \\
\text { ity. } \\
\text { Article History } \\
\text { Received: Okt 28, 2021; } \\
\text { Reviewed: Jan 20, 2022; } \\
\text { Accepted: Jan 30, 2022; } \\
\text { Published: Jan 31, 2022. }\end{array}$ & $\begin{array}{l}\text { The act of utilising all the resources owned by a state, including natural re- } \\
\text { sources, is the right of every state. However, its use is prohibited if it causes } \\
\text { harm to other states. This is then referred to as the principle of no harm rule } \\
\text { in international law. Therefore, each state is responsible not for causing } \\
\text { damage to other States' environments or areas outside the limits of its juris- } \\
\text { diction. This article will analyse the development of the no harm rules and } \\
\text { its application model for claiming state responsibility. As normative re- } \\
\text { search, it used secondary data as the main data, and the primary, secondary } \\
\text { and tertiary legal materials were analysed qualitatively. In discussion, this } \\
\text { principle has long existed as customary international law to mitigate trans- } \\
\text { boundary pollution. In the case of the environment in general, many studies } \\
\text { have applied this principle. However, due to the uniqueness of the climate } \\
\text { change issue, evidence and proof of the impacts caused cannot be used as the } \\
\text { basis for a lawsuit like ordinary environmental cases. Based on the discus- } \\
\text { sion and simulation conducted, it is concluded that the no harm rules princi- } \\
\text { ple can be applied to climate change issues. However, this principle is not } \\
\text { satisfactory and has limitations in its application. }\end{array}$ \\
\hline
\end{tabular}

(C2022; This is an Open Access Research distributed under the term of the Creative Commons Attribution License (https://Creativecommons.org/licences/by/4.0), which permits unrestricted use, distribution, and reproduction in any medium, provided the original works is properly cited.

\title{
INTRODUCTION
}

International law recognises that every state has sovereignty over its natural resources. However, the use of rights to natural resources may not be carried out in ways contrary to the rights of other States as the basis of international law principles. ${ }^{1}$

In international environmental law theory, this principle is referred to as the principle of good neighbourliness or the principle of Sic Utere or No Harm Principle or Nuisance Theory. ${ }^{2}$

1 Patricia Birnie and Alan Boyle, "International Law and The Environment (2nd Ed)," in Oxford Press (London: Oxford Press, 2002), 104.

2 Philippe Sands, "Principles of International Environmental Law. ( 2nd Ed) (Cambridge: Cambridge Universiy Press, 2003), 239. 
Each state is responsible not for causing damage to the environment of other States or to areas outside the limits of its jurisdiction. This principle arises from the Latin proverb sic utere tuo, ut alienum non laedas, which means that a State is responsible not to carry out or permit activities within their territory or public space without regard to or contrary to or the rights of other States to protect the environment. ${ }^{3}$

The Arbitration of the Island of Palmas case stated that all States should "...to protect within the territory the rights of other states, in particular, their right to integrity and inviolability in peace and war". 4 This obligation is studied in more depth in the case of the Trail Smelter, in which the Arbitration then focuses on the damage or loss suffered by the State of America, Washington, due to the presence of harmful fumes, sulphur dioxide emissions from the Smelter located on the Trail, British Columbia Canada. The question posed in this case is whether the Trail Smelter should be asked to stop causing damage to Washington State in the future and, if so, to what extent?. ${ }^{5}$ In answering this question, Arbitration is of the opinion:

"...that, under the principles of international law, as well as of the law of the United States, no State has the right to use or permit the use of its territory in such a manner as to cause injury by fumes in or to the territory of another or the properties or persons therein, when the case is of serious consequence and the injury is established by clear and convincing evidence. ${ }^{\prime 6}$

The above statement can be interpreted that when an activity has serious consequences and the loss occurs clearly with convincing evidence then, no state has the right to use or permit the use of its territory in such a way as to cause damage in or to other areas or property or people in it. According to Sands, this quote is the most widely referenced and has been accepted as a rule of customary international law. ${ }^{7}$ In some cases, this approach to the Arbitration of Trail Smelter case was also used by the International Court of Justice (ICJ). For example, in the case of Corfu Channel, the ICJ stated that it was "...every State's obligation not to allow its territory knowingly to be used for acts contrary to the rights of other States". 8 In the case of the Lac Lanoux Arbitration, it is stated that the state's obligation is to pay attention to the rights and interests of other states in exercising their rights. ${ }^{9}$ Also, in this case, the Arbitration stated, "France [the upstream state] is entitled to exercise her rights; she cannot ignore the Spanish interests. Spain [the downstream state] is entitled to demand that her rights be respected and that her interests be taken into consideration." 10

Likewise, in the case of the Nuclear Test, the ICJ emphasises the legal status of general obligations related to the environment as part of international law, stating as follows: "The existence of the general obligation of states to ensure that activities within their jurisdiction and con-

Boyle, "International Law and The Environment (2nd Ed)."

Island of Palmas Case, "(Netherlands/U.S.A.), 2 R.I.A.A. 829 (Permanent Court of Arbitration 1928)" (n.d.).

"Art. III of the Arbitration Convention between the United States of America and the Dominion of Canada, Signed 15 April" (1935).

6 "Trail Smelter Arbitration (United States v. Canada) 16 April 1938, 11 March 1941; 3 R.I.A.A. 1907 (1941)" (n.d.).

7 Sands, "Principles of International Environmental Law."

8 "Corfu Channel Case (United Kingdom v. Albania), Judgment of 9 April, 1949, I.C.J. Reports 1949" (n.d.).

9 “Affair Du Lac Lanoux (Spain vs France) 12 R.I.A.A. 281, Nov. 16, 1957” (n.d.).

10 Sands, "Principles of International Environmental Law." 
trol respect the environment of other states or areas beyond national control is now a part of the corpus of international law relating to the environment". ${ }^{11}$ (emphasis added)

Climate change involves very complex causal mechanisms. To understand well how anthropogenic climate change occurs, it must be distinguished first naturally or due to activities carried out by humans. It should be understood that Greenhouse Gases (GHGs) and carbon dioxide emissions do not cause direct environmental damage. The concentration of carbon dioxide and other gases in the atmosphere causes the GHGs effect. The increasing concentration of greenhouse gases makes the atmosphere layer thicker. The thickening of the atmospheric layer causes the amount of geothermal heat trapped in the earth's atmosphere to increase, resulting in an increase in the earth's temperature. In the long term, this will cause environmental problems. Examples are the phenomenon of melting ice at the earth's poles which causes water levels to rise, causing flooding, extreme weather that results in a prolonged dry season, heat waves that increase the air temperature in an extreme manner and heavy rains. These conditions cause a lot of environmental problems that impact humans.

Based on the understanding described above, legally proving the existence of a direct relationship between GHGs (Carbon Dioxide, Methane, Nitrogen, etc.) and the impact of environmental damage and loss is very difficult. Therefore, an argument that can link a direct relationship between a state's GHG emissions and environmental damage and losses suffered by other states needs to be developed. So far, the argument for environmental damage and loss due to climate change only refers to reports of scientific evidence in the Intergovernmental Panel on Climate Change (IPCC) report. Under international law, the elements that must be fulfilled in the regime of state responsibility to demand state responsibility for environmental damage and losses due to climate change are unrealistic because GHGs do not directly cause damage and loss. ${ }^{12}$ Therefore, this is an obstacle to proving the existence of a direct causal relationship in implementing the regime of state responsibility in international law for environmental damage and losses due to climate change.

Several legal studies related to the Principle of No Harm Rules and state responsibility to reduce the impact of climate change have been performed, for example, Mara Tignino and Christian Bréthaut, 2020; and Benoit Mayer, 2016. However, those papers only describe the role of this principle in international law on climate change issues and they do not analyse how and whether it can be applied in practice to claim state responsibility.

Based on the description above, the problem raised in this article is how to develop and apply the No Harm Rules Principle to claim state responsibility for the impacts of climate change. This article discusses the development of the no-harm rule principle, discusses the constraints, and simulates a model for applying the principle in practice. For this reason, this article will be divided into several discussion topics. First, it will discuss the regime of state responsibilities in international law regarding the impact of climate change and the development of the principle of no harm rule in international conventions related to the environment. Secondly, it

11 ICJ advisory on nuclear weapons, “Advisory Opinion on the Legality of Nuclear Weapons," July ICJ Judgement § (1996), https:/www.icj-cij.org/files/case-related/95/095-19960708-ADV-01-00-EN.pdf.

12 Mada Apriandi Zuhir, "Rethinking Legality of State Responsibility on Climate Change in International Law Perspectives," Jurnal Dinamika Hukum 17, no. 2 (2017): 203-14, https://doi.org/10.20884/1.jdh.2017.17.2.801. 
will be analysed model for applying the no-harm rule principle to claim state responsibility for environmental damage and losses due to climate change. The final section will conclude the overall results of the discussion.

\section{RESEARCH METHODS}

The study used a juridical approach by logically examining the legal aspects that underlie the no-harm rule principle, its application in international conventions related to the environment, and how it was applied through a model to claim state responsibility for environmental damage and losses due to climate change. Therefore, the research specification used descriptiveanalytical. In this study, the leading data was secondary data (primary, secondary and tertiary legal materials). Furthermore, the research data obtained were analysed qualitatively.

\section{ANALYSIS AND DISCUSSION}

\section{The regime of State Responsibilities in International Law Regarding the Impact of Cli- mate Change}

The use of the term "state responsibility" may result in a misunderstanding that assumes that the state is the only subject of international law, while international organisations, ICRC, Vatican, Belligerents and individuals are not. ${ }^{13}$ The obligation to respect and prohibit harming and violating other states' rights is a basic principle in international law and international relations. Violation of this fundamental principle will result in a claim of responsibility for the violating state. According to Shaw, "...this responsibility arises both because of the nature of international law and arises from the concept of state sovereignty and equality among the States". ${ }^{14}$ Under Chapter V, United Nations General Assembly (UNGA) Resolution 56/83, a state that violates the rights of another state is required to provide compensation as a result of the loss caused. Circumstances precluding wrongfulness are consent, self-defence, countermeasures regarding an internationally wrongful act, force majeure, distress, necessity, compliance with peremptory norms, and consequences of invoking an internationally wrongful act a circumstance precluding wrongfulness (Art. 20-27 UNGA Res 56/83). ${ }^{15}$

In the international law literature, the state's responsibility is divided into two: 1) liability due to unlawful acts known as delictual liability. This type of responsibility arises from every mistake or negligence of a state towards foreigners in its territory or the territory of another state. For instance, responsibilities arising from space exploration, nuclear exploration, or other activities across national borders; and 2) liability for contractual liability which arises from a state's breach of an agreement or contract. ${ }^{16}$

Two theories underlie state responsibility, namely the theory of risk and error. The theory of risk determines that a State is absolutely responsible for every activity that causes hazardous effects (harmful effects of hazardous activities) even though the activity is legal. This theory underlies the principle of absolute liability, strict liability, or objective responsibility. ${ }^{17}$ An ex-

13 Sands, "Principles of International Environmental Law."

14 Malcolm N. Shaw, International Law (6th Ed) (Cambridge University Press, 2008).

15 United Nations General Assembly (UNGA) Resolution 56/83

16 Huala Adolf, Aspek-Aspek Negara Dalam Hukum Internasional (JAKARTA, 1991). and Shaw, International Law (6th Ed).

17 Adolf, Aspek-Aspek Negara Dalam Hukum Internasional. 
ample of the application of this theory can be seen in the provisions of Article 2 of the Liability Convention 1972, which states that the launching state is absolutely responsible for paying compensation for losses on the earth's surface or on aircraft that are in flight where the losses and the accident were caused by its space objects.

In the theory of error (fault theory), the state's responsibility arises when the state's actions can be proven to contain an element of error. An act is said to contain errors if the act is done intentionally (dolus) or by negligence (culpa) which cannot be justified. This error theory then underlies the principle of personal responsibility or liability based on fault. ${ }^{18}$ The presence of a dolus element means that the perpetrator state acts in a certain way, willed or known with the intent to cause injury or harm. The dolus element can help determine attribution and infringement issues and the extent of the effect on the injury or loss incurred.

Meanwhile, culpa is an action that can be blamed because of an element of error, carelessness or negligence because the steps that should have been taken to avoid an adverse event were not taken. In situations where individual actions that result in damage and loss and those actions are not related to the state, a state may be held liable for failing to exercise oversight. ${ }^{19}$ An act of a state that can be blamed according to international law (wrongful act) if; 1) when the act can be attributed to that state; and 2) when the state's actions have violated its international obligations. ${ }^{20}$

Until the end of the 20th century, it was still believed that the emergence of state responsibility was not enough with the two elements above, but rather that there must be an element of damage or loss to other parties or States. In its later development, the element of damage or loss is no longer considered a necessity in every case that can result in state responsibility, for example, violations of international law provisions relating to human rights. This violation of human rights is clearly an act that is blamed according to international law, even though it does not harm other parties or States. ${ }^{21}$

Article 24 of the European Convention on Human Rights states that each State party is allowed to file an objection against other Parties without requiring the state that objects to be a victim of human rights violations committed by the state suspected of committing the violation. Likewise, Article 3 of the Annex to the Resolution of the United Nations General Assembly No. 56/83 dated 28 January 2002 concerning the Responsibility of States for internationally wrongful acts (hereinafter referred to as UNGA Res. 56/83) which eliminates the condition for damages related to acts that can be blamed under international law. Articles of UNGA Res. 56/83 on State responsibility for an internationally wrongful act provides simultaneously general rules of international law that reflect customary law with rules in the environmental field that arise from treaties and other international rules. ${ }^{22}$

In the environmental field, in addition to the articles contained in UNGA Res. 56/83, there are also several non-binding instruments relating to state obligations. Several non-binding international instruments regulate the obligations and responsibilities of this state, for example,

8 Adolf.

19 Ian Brownlie, Principles of Public International Law (2nded) (London, UK: Oxford University Press, 1973).

20 International Law Commission, "Draft Articles on Responsibility of States for Internationally Wrongful Acts" (2021).

21 Shaw, International Law (6th Ed).

22 Sands, "Principles of International Environmental Law." 
the following statement from the Brundtland Commission or the World Commission on Environment and Development (WCED).

"If one or more activities create a significant risk of substantial harm as a result of a transboundary environmental interference, and if the overall technical and socio-economic cost or loss of benefits involved in preventing or reducing such risks far exceeds, in the long run, the advantage which such prevention or reduction would entail . . . the state which carried out or permitted the activities shall ensure that compensation is provided should substantial harm occur in an area under the national jurisdiction of another state or in an area beyond the limits of national jurisdiction." 23

This statement is also in line with UNEP Principle 12, 1978, which states that states are responsible for fulfilling their international environmental obligations concerning the use of shared natural resources and that states are subject to obligations relating to the implementation of international law for environmental damage arising from violations against this obligation outside the boundaries of their jurisdiction. ${ }^{24}$

Recognition of these practices of international responsibility has existed for a long time and can be seen in decisions of international courts, such as the Permanent Court of International Justice (PCIJ) and the International Court of Justice (ICJ), which state that international responsibility arises immediately after a state commits an act. That violates the rights of other States. ${ }^{25}$ PCIJ in the case of the Spanish Zone of Morocco claims, stated; “...responsibility is the necessary corollary of a right. All rights of an international character involve international responsibility. Responsibility results in the duty to make reparation if the obligation in question is not met." 26

Likewise, in the case of the Chorzow factory (1928), the PCIJ stated that: "it is a principle of international law and even a greater conception of law that any breach of an engagement involves an obligation to make reparation". ${ }^{27}$ The responsibility of the state for wrongful act according to international law is the most important thing to do is the obligation to stop the act, ensure and properly guarantee that there will be no repetition of the act if there is a possibility of it happening and make full compensation for the losses caused by the wrongful act. ${ }^{28}$

This obligation for compensation is sometimes called a liability. According to Sands, the term 'liability' in the international legal literature has been widely discussed. For example, PM Dupuy and H. Smets define liability as an international obligation to provide compensation. At the same time, LFE Goldie gives a broader meaning: the consequences of failure to perform duties or comply with required performance standards. Therefore, this liability has the connotation of legal compensation when responsibilities and losses arising from failure to fulfil those obligations. $^{29}$

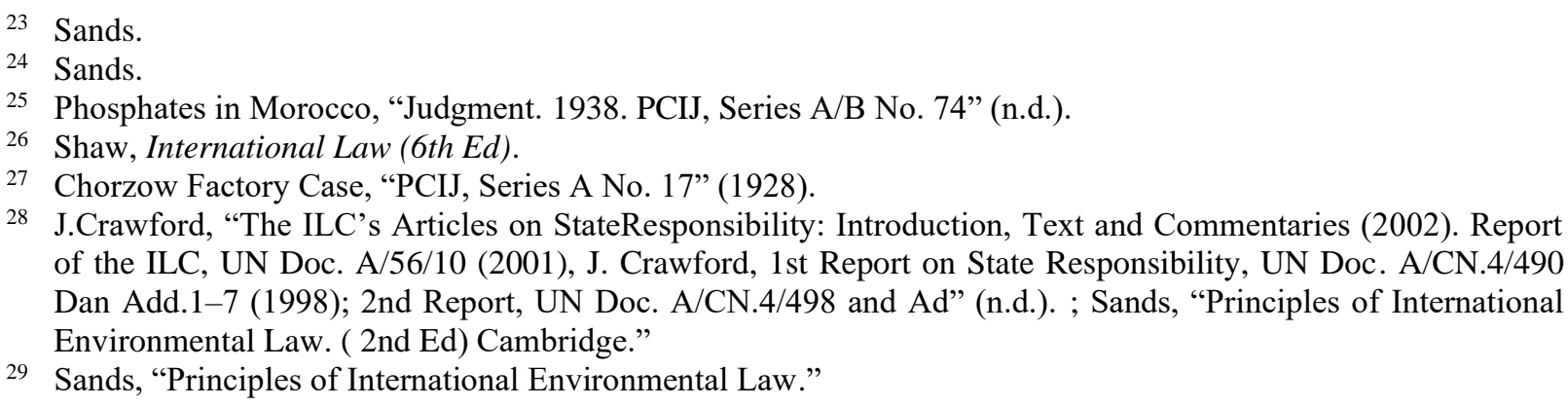

J.Crawford, “The ILC's Articles on StateResponsibility: Introduction, Text and Commentaries (2002). Report of the ILC, UN Doc. A/56/10 (2001), J. Crawford, 1st Report on State Responsibility, UN Doc. A/CN.4/490 Dan Add.1-7 (1998); 2nd Report, UN Doc. A/CN.4/498 and Ad" (n.d.). ; Sands, "Principles of International Environmental Law. ( 2nd Ed) Cambridge."

29 Sands, "Principles of International Environmental Law." 
This rule is also applied in many cases by the ICJ, for example, the Corfu Channel case and the Danube Dam Case (Gabcikovo-Nagymaros Project). ${ }^{30}$ Although the explanation above describes the state's responsibility that arises because of an error, it should also be explained that a state's responsibility arises without any wrongful act. In this case, the causal relationship between the activity and the damage done leads to an obligation to pay compensation, even though the damage arises from legally valid activities. This is due to the development of science and technology, which on the one hand, creates significant benefits for society, but on the other hand often has a certain level of risk of negative impacts, such as the production of nuclear energy and activities in outer space. Thus, regulations concerning special obligations are also contained in several international agreements that regulate these activities. For example, in Article III (1) of the International Convention on Civil Liability for Oil Pollution Damage 1969, it is stated that "the owner of a ship at the time of an incident... shall be liable for any pollution damage caused by oil which has escaped or been discharged from the ship as a result of the incident". Similarly, at the Paris Convention on Third Party Liability in the Field of Nuclear Energy 1960, the Brussels Convention Supplementary to the Paris Convention 1963 and the Vienna Convention on Civil Liability for Nuclear Damage 1963. In general, the agreement that contains the rules regarding this obligation contains civil liability. This means that only the operator or owner of a particular activity is obliged to pay compensation for the impacts caused by the activity. Concerning accidents caused by these activities, the compensation given is usually limited to a certain amount of insurance money, where the process of claiming responsibility is in the national court.

\section{Stockholm Declaration 1972}

With regard to international instruments on the environment, the 1972 Stockholm Conference agreed on an agreement contained in 26 principles of environmental management called the Stockholm Declaration. It produced 109 recommendations as part of its action plan. Although according to Birnie and Boyle, "the legal status of the entire instrument of the Stockholm Declaration is still undefined, but it is often referred to in international treaties, international agreements and other documents and is recognised as evidence of state practice and is an example of soft law". ${ }^{31}$ One of the essential points and the main principle of this Declaration is Principle 21, which formulates;

"States have, in accordance with the Charter of the United Nations and the principles of international law, the sovereign right to exploit their own resources pursuant to their own environmental policies, and the responsibility to ensure that activities within their jurisdiction or control do not cause damage to the environment of other States or of areas beyond the limits of national jurisdiction."

In 1997, the United Nations General Assembly passed resolution 2996, which stated that Principles 21 and 22 of the Stockholm Declaration lay down the basic principles of the environment. Principle 21 includes two fundamental objectives of international environmental law: stipulate that states have sovereign rights over their natural resources and the principle of no harm.

30 Martin Dixon and Robert McCorquodale, Cases and Materials on International Law (Oxford University Press, 2003).

31 Boyle, "International Law and The Environment (2nd Ed)." 
This understanding of the no-harm principle was then developed in other areas and areas outside the boundaries of national jurisdiction. ${ }^{32}$ The effect of Principle 21 regarding its normative character is also recognised in Articles 192, 193 and 194 of the United Nations Convention on the Law of the Sea (UNCLOS 1982) and the Convention on the Transboundary Effects of Industrial Accidents) 1992.

\section{Rio Declaration 1992}

After the Stockholm Conference, 20 years later, the United Nations held a summit in Rio de Janeiro on June 3-4, 1992. This conference was called the United Nations Conference on Environment and Development (UNCED), known as the Earth Summit or Rio Summit. Although not legally binding as is the Stockholm Declaration, the Rio Declaration is a significant example of soft law instruments for the development and codification of international law. The preamble of the 1992 Rio Declaration explicitly stated, “...its adoption by consensus of 176 states, after a prolonged negotiation process, and its normative character, make it a crucial example of the use of soft law instruments in the process of codification and development of international law."

The main concerns of the Rio Declaration are sustainable development and the global environment. In the context of environmental transboundary hazards and risks, the Rio Declaration contains important principles formulated in Principles 2, 18, and 19. ${ }^{33}$ Principles 21 of the Stockholm Declaration and Principle two of the Rio Declaration declare that the no-harm rule applies equally to territorial areas and transboundary jurisdiction.

\section{No Harm Rule as a Basis for Claims for Loss and Environmental Damage Due to Climate Change}

The development of the principle of state responsibility starting from the sic utere or no harm principle or the principle of good neighbourliness from the Trail Smelter case decision and principle 21 of the 1972 Stockholm Declaration and Principle 2 of the 1992 Rio Declaration has become part of customary international law or even jus cogens which legally binding all States regardless of whether a State is a state party or not to an international treaty.

As explained in the previous section, the earth's atmosphere is a different kind of region related to climate change. The atmosphere is a layer of airflow that continuously moves in different areas regardless of the jurisdictional boundaries of a state, so it is different from airspace. ${ }^{34}$ According to international law, the territory of a state consists of three dimensions, namely land, sea and air. ${ }^{35}$ The traditional concept in international law related to state sovereignty perceives airspace as unlimited (usque ad coelum), although later, this perception was corrected in air and space law that the airspace over the high seas is open to everyone. ${ }^{36}$

Seas outside the national jurisdiction of States are called high seas. The utilisation of the high seas is carried out based on the principle of the common heritage of mankind, which

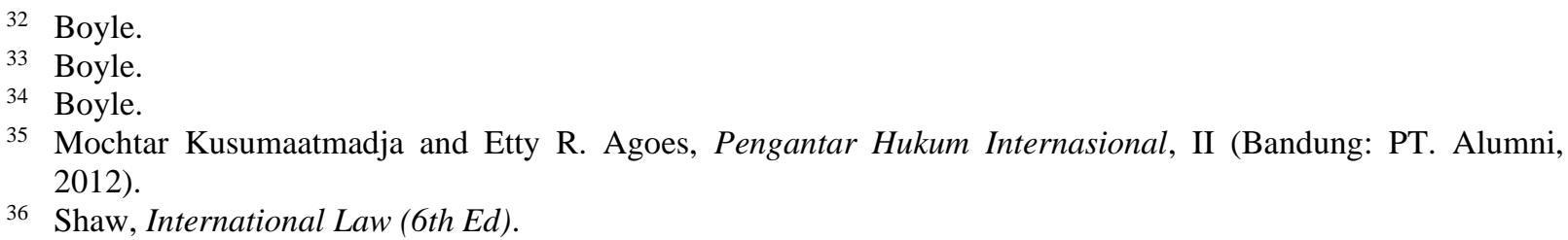


means that the benefits of the high seas, both aspects of navigation and aspects of natural resources in it, must be enjoyed by all mankind and should not be monopolised by one or several states only. This principle gives each state's general rights and obligations towards the high seas and special rights and obligations on the particular high seas, such as providing adequate search and rescue (SAR) facilities, hot pursuits, and the preservation of the marine environment. ${ }^{37}$

The United Nations General Assembly stated through Resolution 43/53, Vienna Convention for the Protection of the Ozone Layer 1985, and UNFCCC 1992 stipulate that the global atmosphere is a common concern of humankind. According to Birnie and Boyle, the use of this term by giving the label common concern is a form of political compromise, in which the term previously offered is the common heritage of humankind. ${ }^{38}$ Therefore, the use of the common concern label has a different legal status from the term common heritage of humankind which indicates natural resources such as permanent sovereignty, public property, shared resources, or a common heritage. The relationship between each issue is simply illustrated in Figure 1 and qualitatively explained in the following paragraph.

Figure 1: Flowchart, the Model for Implementing the No Harm Rule on State Responsibilities in the Climate Change Regime

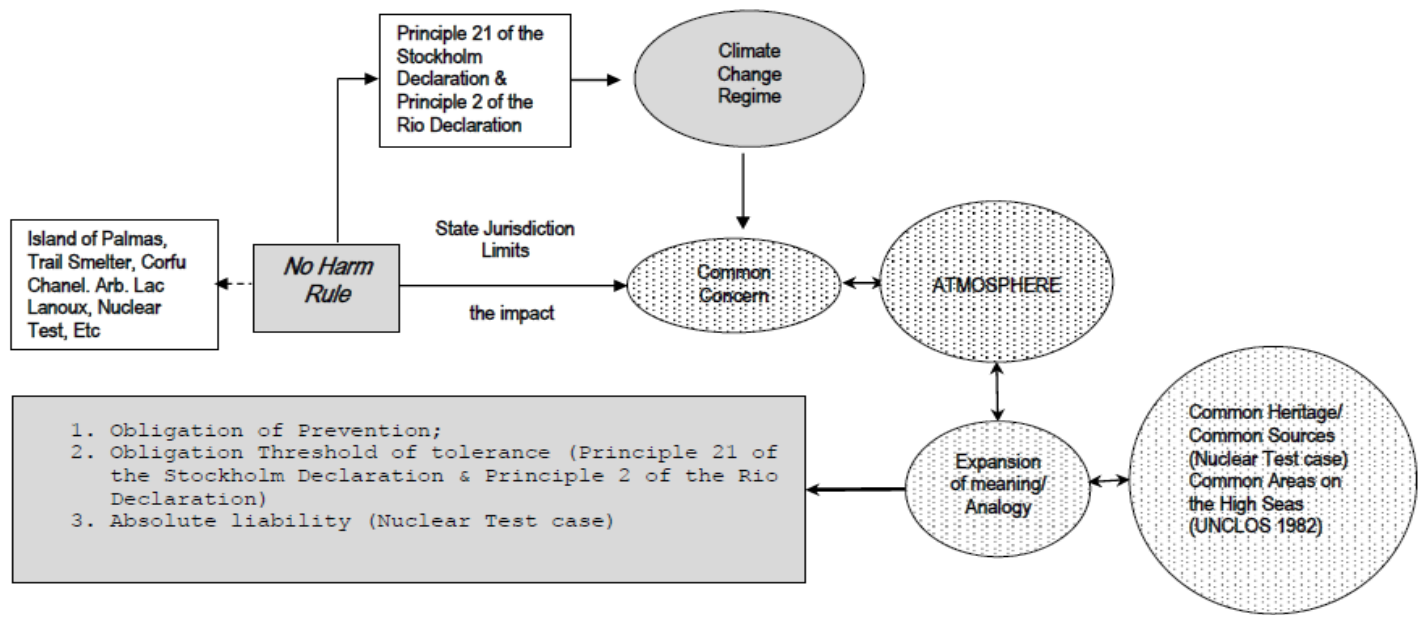

The term common concern used in the global atmosphere does not make the atmosphere a public property outside the state's sovereignty. However, because it is preserved in the same way as the ozone layer, the global atmosphere is a common source of the vital interests of humankind. ${ }^{39}$

For this reason, so that the no-harm rule principle can be applied to the issue of global climate change, the scope of Principle 21 of the 1972 Stockholm Declaration and Principle 2 of the 1992 Rio Declaration must be developed by expanding the meaning or understanding of the

\footnotetext{
37 "The Provisions Regarding the Legal Regime of the High Seas as Stated in UNCLOS 1982 Are Contained in Part VII, Articles 86 to 120, Applies to All Parts of the Sea Outside the Inland Sea, Territorial Sea and EEZ. In Essence, These Provisions Are the Same A" (n.d.).

38 Boyle, "International Law and The Environment (2nd Ed)."

39 Boyle.
} 
atmosphere extensively. At least the notion of the atmosphere can be analogised by equating it with the protection of common areas as applied to the high seas. ${ }^{40}$

Thus, if we can make an analogy, then the preamble to the 1985 Vienna Convention on the Protection of the Ozone Layer which includes Principle 21 of the 1972 Stockholm Declaration in its preamble as well as the intrinsic rules mentioned in the Preamble of the UNFCCC can also be used as a legal basis for applying the principle of good neighbourliness to climate change issues in general and atmospheric issues in general.

In addition, international practice in respecting the rights of other States related to nuclear testing in the atmosphere, as also stated by Birnie and Boyle, can be used as a reference for the application of this principle to the atmosphere. ${ }^{41}$ So then, if there is a State that opposes or does not want to recognise climate change as a common concern of humankind, it is the same as opposing and unwilling to carry out its obligations on climate change as a global concern.

In relation to the principle of no harm rule, several things must be considered in its implementation, namely:

\section{Obligation to Take Prevention}

This precautionary principle can be found in the formulation of Article 2 of the UNFCCC, which states;

"The ultimate objective of this Convention and any related legal instruments that the Conference of the Parties may adopt is to achieve, in accordance with the relevant provisions of the Convention, stabilisation of greenhouse gas concentrations in the atmosphere at a level that would prevent dangerous anthropogenic interference with the climate system. Such a level should be achieved within a time-frame sufficient to allow ecosystems to adapt naturally to climate change, to ensure that food production is not threatened and to enable economic development to proceed in a sustainable manner." (Emphasis added)

Observing Article 2 of the UNFCCC, it can be said that the formulation of this article contains an explicit preventive principle as contained in the formulation of the objectives of the Convention, which requires state parties to stabilise GHGs concentrations in the atmosphere. This principle states that every state is required to prevent, decrease, limit or control activities that may result in or pose a risk of environmental damage. According to Sands, the obligation not to cause harm arises as a limitation to the principle of sovereignty. This principle also applies within the territory of the state that caused it. ${ }^{42}$ Added by Sands, the purpose of this principle is only one, namely, minimising environmental damage. In the case of the GabcikovoNagymaros Project, the ICJ stated that "in the field of environmental protection, vigilance and prevention are required on account of the often-irreversible character of damage to the environment and the limitations inherent in the very mechanism of reparation of this type of damage." 43

In the Decision, the ICJ emphasised that in the field of environmental protection, vigilance and prevention are needed considering the nature of environmental damage that is often irreversible and the limitations inherent in reparation mechanisms for this type of damage. This principle can also be found in the Trail Smelter Arbitration case through an order to Canada to

Boyle.

41 Boyle.

42 Sands, "Principles of International Environmental Law. ( 2nd Ed) Cambridge."

43 Gabčíkovo-Nagymaros Project case (Hungary/ Slovakia), "Judgment, I.C.J. Reports 1997” (n.d.). 
prevent future injury. ${ }^{44}$ and implicitly seen in the Lac Lanoux Arbitration. ${ }^{45}$ This precautionary principle is also supported in most international environmental agreements, which aim to prevent: 1) extinction of flora and fauna species; 2) the spread of occupational diseases, including radioactive contamination to workers; 3 ) introduction and spread of pests and diseases; 4) pollution of oil in the sea, radioactive waste, hazardous and toxic materials and waste (B3), from land sources, or from any source; 5) river pollution; 6) atmospheric radioactive pollution; 7) harmful environmental modifications; 8) the opposite effect of activities that can prevent the migration of species; 9) air pollution; 10) modification of the ozone layer; 11) degradation of the natural environment; 12) all pollution; 13) significant adverse environmental impacts; 14) transboundary impacts in general; 15) harmful anthropogenic disturbances to the climate system; 16) loss of fisheries and other biodiversity, including as a result of the release of genetically modified organisms; and 17) damage to health and the environment from resistant chemicals and organic pollutants. ${ }^{46}$

\section{Liability Over Tolerance Threshold}

In addition, related to the principle of no harm rule and the principle of prevention, studies related to the threshold of tolerance are also crucial because as Principle 21 of the 1972 Stockholm Declaration and Principle 2 of the 1992 Rio Declaration formulate: "the responsibility to ensure that activities within their jurisdiction or control do not cause damage to the environment of other States or of areas beyond the limits of national jurisdiction"

Subject to these principles, it is the responsibility of States to take adequate steps to control and regulate transboundary sources of severe or harmful environmental pollution in their territory or subject to their jurisdiction. Interestingly then, apart from stimulating the state's obligation to control so that there is no damage to the environment within their jurisdiction, it also recognises state sovereignty over natural resources within that jurisdiction. Thus, it is understood that these principles provide limited sovereignty for the state to exploit their natural resources, and at the same time, it can also be interpreted not to prohibit environmental damage absolutely. ${ }^{47}$ The exploitation of natural resources, like it or not, will definitely damage the environment. Development by exploiting natural resources, on the one hand, serves to improve the quality of human life but, on the other hand, also results in a decline in the quality of human life. Therefore, there must be a tolerance level of damage that provides a threshold. This tolerance threshold must be based on specific quality standards. However, there are no international rules that specifically regulate this quality standard that can be used to determine what types of environmental damage can be attached to responsibility. Therefore, the obligation to prevent cross-border damage must be attached with minimal (de minimis) requirements. ${ }^{48}$ For this reason, legal scholars generally agree that only significant or severe damage can trigger the no harm-rule principle as a preventive obligation. ${ }^{49}$ Trail Smelter Arbitration uses the term stand-

\footnotetext{
44 Trail Smelter Arbitration (United States v. Canada) 16 April 1938, “11 March 1941; 3 RIAA 1907 (1941) Part 4, Section 3.No Title" (n.d.).

45 Sands, "Principles of International Environmental Law." 247.

46 Sands.

47 Boyle, "International Law and The Environment (2nd Ed)."

48 Boyle.

49 Sands, "Principles of International Environmental Law."
} 
ard quality of tolerance threshold with the sentence as a serious consequence. ${ }^{50}$ Likewise, for example, the term used in Article 1.1 of the UNFCCC which contains the meaning of the adverse effects of climate change by using the term significant deleterious effects. The terms significant, appreciable, substantial, and severe are often used to describe the tolerance threshold in international court decisions and international agreements related to environmental protection, even though using these terms gives a quite tricky understanding of the quantity of damage that occurred. ${ }^{51}$ The quality of this tolerance threshold standard, for example, can be seen from the formulation of Article 1 of the 1979 Convention on Long-Range Transboundary Air Pollution. It is stated that the pollution in question must lead to deleterious effects of such a nature as to endanger human health, harm living resources and ecosystems and material property and impair or interfere with amenities and other legitimate uses of the environment. Due to the absence of a specific standard rule regarding this tolerance threshold, as stated by Shaw, the relativity of the issue at hand and the importance of a particular case must be seen as insignificant factors. ${ }^{52}$

\section{Absolute Liability}

The responsibility not to cause damage as contained in Principle 21 of the 1972 Stockholm Declaration and Principle 2 of the 1997 Rio Declaration above also raises the question of whether this responsibility is an absolute liability or a strict liability. According to Shaw, some experts argue that the appropriate standard for the state to act is strict liability in the environmental field. ${ }^{53}$ If all accept this opinion, then the state has an absolute obligation to prevent damage and can be held responsible for the damage that occurs regardless of the fault. However, the formulation of Principle 21 of the 1972 Stockholm Declaration and Principle 2 of the 1997 Rio Declaration is not very clear regarding this issue, and neither is international practice such as the Trail Smelter Arbitration, Corfu Channel, ${ }^{54}$ and Gut Dam Arbitration. In the case of the Trail Smelter, which has a tremendous influence on international discussion and practice regarding the principle of good neighbourliness, especially the principle of no harm, it is not clear whether the responsibility is absolute. Observing the Trail Smelter case, it is difficult to conclude that the state's responsibility is absolute to not cause damage because, from the beginning of the case, the Canadian Party has accepted this responsibility. In the case of the Corfu Channel, Albania's liability arising from its failure to alert two British ships and other voyages of mining activity in their territorial waters does not constitute a form of strict liability. Likewise, with the case of Gut Dam Arbitration (1968), ${ }^{55}$ construction of a dam for navigation facilities on the river St. Laurence by Canada has been known by the United States. Even the two States have agreed that Canada will provide compensation if there are losses from these development activities that have an impact on American citizens. The development of this fundamental responsibility theory can then be seen in the problem of damage caused by nuclear activity and damage in space. In Article 2 of the Liability Convention 1972, it is stated that the

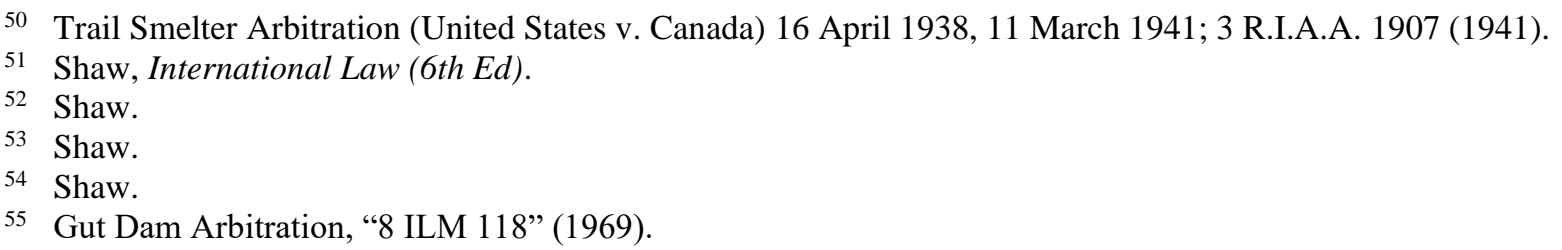


launching state is absolutely responsible for paying compensation for losses on the earth's surface or on aircraft that are in flight where the losses and accidents are caused by their celestial objects. In the case of nuclear tests, nuclear test activities will bring about substantial damage even though they are carried out under normal conditions and anthropogenic activities that emit GHGs. If then nuclear test activities are not prohibited, but if damage occurs due to these activities, then the state's responsibility is absolute. Thus, as Voigt said, these consequences should also be applied to GHGs emissions that are legally emitted. ${ }^{56}$ In this context, then, the case of the Trail Smelter becomes relevant when the production activity of the Trail Smelter itself is not prohibited. However, the emission of sulphur dioxide that exceeds the tolerance limit is carried by air, disturbing the environment.

They are observing the things that need to be considered in applying the no-harm rule, namely the obligation to prevent, the obligation to the tolerance threshold, and the absolute obligation, as Birnie and Boyle said that the principle of no harm could be interpreted as absolute responsibility. However, when discussing aspects of ecology and development, the issue of absolute responsibility will certainly face enormous challenges and resistance from States in the world. ${ }^{57}$

In addition, absolute responsibility focuses on the results, namely the impact and the burden of proof. The results or consequences arising from an activity and the burden of proof are the main issues when discussing claims of state responsibility under internationally applicable regimes. So that these two approaches, both the approach based on the regime of state responsibility and the approach to the principle of no harm rule, are not very satisfactory to be used as the basis for claiming state responsibility for environmental losses and damage due to the impact of climate change.

\section{CONCLUSION}

Based on the ICJ decision related to the Nuclear Test case, it can be interpreted that the existence of a general obligation of states to ensure that activities within their jurisdiction and control in respect of the environment of other States or areas beyond their national control are currently part of the corpus of international law. However, related to the development and application model of the No-Harm Rule principle as described earlier, if the focus is on the activity or conduct as formulated in the climate change instruments, not on the results or consequences (impacts), such as in the nuclear test, the No-Harm Rule principle is difficult to apply in practice to claim state responsibility for environmental losses and damage due to the impacts of climate change, because this principle does not look at behavioural activities or actions taken by a State. Therefore, it can then be concluded from the simulation and model application of the no-harm rule principle on the impacts of climate change as the basis for claiming state responsibility is not sufficient. This is because a direct relationship between the fulfilment of state obligations and the impact of climate change is difficult to prove as a direct relationship between cause and effect on environmental damage in general.

\footnotetext{
56 Christina Voigt, "State Responsibility for Climate Change Damages," Nordic Journal of International Law 77, no. 1 (2008): 8.

57 Boyle, "International Law and The Environment (2nd Ed)."
} 


\section{REFERENCES}

Adolf, Huala. Aspek-Aspek Negara Dalam Hukum Internasional. (Jakarta: Rajawali Pers, 1991).

Boyle, Patricia Birnie and Alan. "International Law and The Environment (2nd Ed)." (London: Oxford Press, 2002).

Brownlie, Ian. Principles of Public International Law (2nded). (London: Oxford University Press, 1973).

Chorzow Factory Case. PCIJ, Series A No. 17 (1928).

Commission, International Law. Draft Articles on Responsibility of States for Internationally Wrongful Acts (2021).

Corfu Channel case (United Kingdom v. Albania), Judgment of 9 April, 1949, I.C.J. Reports 1949 (n.d.).

Crawford, James. The ILC's Articles on StateResponsibility: Introduction, Text and Commentaries (2002). Report of the ILC, UN Doc. A/56/10 (2001), J. Crawford, 1st Report on State Responsibility, UN Doc. A/CN.4/490 dan Add.1-7 (1998); 2nd Report, UN Doc. A/CN.4/498.

ICJ advisory on nuclear weapons. Advisory opinion on the Legality of Nuclear Weapons, July ICJ Judgement \& (1996). https://www.icj-cij.org/files/case-related/95/095-19960708ADV-01-00-EN.pdf.

Island of Palmas Case. (Netherlands/U.S.A.), 2 R.I.A.A. 829 (Permanent Court of Arbitration 1928) (n.d.).

Kusumaatmadja, Mochtar and Etty R. Agoes. Pengantar Hukum Internasional. II. (Bandung: PT. Alumni, 2012).

Lake Lanoux Arbitration, Affair du Lac Lanoux (Spain vs France). 12 R.I.A.A. 281, Nov. 16, 1957.

McCorquodale, Martin Dixon and Robert. Cases and Materials on International Law. Oxford University Press, 2003.

Permanent Court of Arbitration. Morocco, Phosphates in Judgment. 1938. PCIJ, Series A/B No. 74.

Sands, Philippe. "Principles of International Environmental Law. ( 2nd Ed) (Cambridge: Cambridge University Press, 2003).

Shaw, Malcolm N. International Law (6th Ed). Cambridge University Press, 2008.

International Court of Justice, Gabčíkovo-Nagymaros Project Case: Hungary v. Slovakia. Judgment, I.C.J. Reports 1997.

The Arbitration Convention between the United States of America and the Dominion of Canada, signed 15 April (1935).

The Gut Dam Arbitration. 8 ILM 118 (1969).

The United Nations, Reports of International Arbitral Awards: Trail Smelter Arbitration (United States v. Canada) 16 April 1938, 11 March 1941; 3 R.I.A.A. 1907 (1941).

Trail Smelter Arbitration (United States v. Canada) 16 April 1938, 11 March 1941; 3 R.I.A.A. 
1907 (1941) (n.d.).

United States v. Canada, Trail Smelter Arbitration. 11 March 1941; 3 RIAA 1907 (1941) Part 4, Section 3.

Voigt, Christina. "State Responsibility for Climate Change Damages." Nordic Journal of International Law 77, no. 1 (2008): 8.

Zuhir, Mada Apriandi. "Rethinking Legality of State Responsibility on Climate Change in International Law Perspectives." Jurnal Dinamika Hukum 17, no. 2 (2017): 203-14. https://doi.org/10.20884/1.jdh.2017.17.2.801. 